\title{
Contestations Over Classifications: Latinos, the Census and Race in the United States
}

\section{Clara E. Rodríguez}

\section{(2) OpenEdition \\ 12 Journals}

Electronic version

URL: https://journals.openedition.org/jsa/11062

DOI: 10.4000/jsa.11062

ISSN: 1957-7842

\section{Publisher}

Société des américanistes

\section{Printed version}

Date of publication: 5 December 2009

Number of pages: 175-205

ISSN: 0037-9174

\section{Electronic reference}

Clara E. Rodríguez, "Contestations Over Classifications: Latinos, the Census and Race in the United States", Journal de la Société des américanistes [Online], 95-2 | 2009, Online since 10 December 2014, connection on 04 September 2022. URL: http://journals.openedition.org/jsa/11062 ; DOI: https:// doi.org/10.4000/jsa.11062 


\title{
CONTESTATIONS OVER CLASSIFICATIONS: LATINOS, THE CENSUS AND RACE IN THE UNITED STATES
}

\author{
Clara E. RODRÍGUEZ *
}

The divergence between popular and state classifications of peoples has become increasingly important with the growing migration of peoples around the world. This paper examines this issue by focusing on one group (Latinos in the US) at one historical juncture (the late 20th-early 21 st centuries). After examining the evolution of US census " race » categories in the context of shifting political, economic, and scientific trends, it reviews Hispanic/Latinos' responses to questions of " race » on the US census and the theories that have surfaced to explain why so many Latinos choose the "Some Other Race " category on the census. It also chronicles the US government's efforts to discourage such responses and force Latinos into more traditional US race categories. The global uniqueness of the US's « race » concept is also underscored. [Key words: race, ethnicity, classifications, social construction of race, census, Hispanics, Latinos, United States, France.]

Débats autour des classifications: les latinos, le recensement et la question raciale aux États-Unis. Les divergences entre les classifications courantes des individus et celles des États ont gagné en importance avec l'augmentation du nombre de personnes immigrées à travers le monde. Cet article ne traite que d'un groupe, celui des Latinos aux États-Unis, à ce point de contact entre la fin du $\mathrm{xx}^{\mathrm{e}}$ siècle et le début du $\mathrm{xxI}^{\mathrm{e}}$ siècle. Après avoir rappelé l'évolution des catégories de " races » dans le recensement nordaméricain, ce dans le contexte politique, économique et scientifique changeant des dernières décennies, on s'intéressera à la réponse des Hispaniques/Latinos à la question de la « race " et aux explications qui ont été données au pourquoi du choix que tant d'entre eux ont fait de la catégorie " autre race». On fera aussi l'historique des efforts du gouvernement des États-Unis pour décourager une telle réponse et forcer les Latinos à se positionner dans des catégories de races plus traditionnelles. Le place du concept de " race », unique aux États-Unis, sera également soulignée. [Mots-clés: race, ethnicité, classifications, construction sociale des races, recensements, Hispaniques, Latinos, États-Unis, France.]

* Professor, Fordham University, Dept. of Sociology and Anthropology, 113 W. 60 St., New York, New York 10023, États-Unis [crodriguez@Fordham.edu].

Journal de la Société des Américanistes, 2009, 95-2, pp. 175-205. OSociété des Américanistes. 
Divergencias sobre las clasificaciones: los latinos, el censo y las razas en los Estados Unidos. Las divergencias entre las clasificaciones comunes de la gente y las de los estados ha crecido sustancialmente con el aumento de las migraciones a nivel mundial. En ese trabajo se tratará de un solo grupo, los latinos en los Estados Unidos, entre el final del siglo xx y el inicio del siglo xxi. Después de haber revisado la evolución de las categorías raciales utilizadas por los censos de los Estados Unidos en el marco de las transformaciones políticas, económicas y científicas recientes, se examinarán las respuestas de los latinos a la pregunta sobre la(s) raza(s) y las interpretaciones que se han venido dando al porqué de su elección - tan frecuente - de la categoría "Otra raza ». Se revisarán también los esfuerzos que el gobierno de los Estados Unidos ha realizado para controlar este tipo de respuesta y forzar a los latinos a elegir una categoría racial más tradicional. Se discute igualmente el concepto de raza tal como se aplica de forma sin equivalente en los Estados Unidos. [Palabras claves: raza, etnicidad, clasificaciones, construcción social de las razas, censo, hispanos, latinos, Estados Unidos, Francia.]

As Morning (2008) notes, governments vary with regard to how they count their populations. Some use a simple count of individuals, as in France. Others also count categories of people, but not all use the same categories and the meanings given to the categories vary from country to country and sometimes within a country. "What is called "race" in one country might be labeled "ethnicity" in another... nationality means ancestry in some contexts and citizenship in others. Even within the same country, one term can take on several connotations, or several terms may be used interchangeably " (Morning 2008, p. 240). Despite these variations, the categories generally reflect and support the scientific discourse and milieu of the nation at any given point in time. The categories used by governments ostensibly reflect group boundaries; but they may also reinforce, create and perpetuate group boundaries and hierarchies. Finally, the categories may also be contested by the categorized. This paper analyzes an example of such a contestation. It focuses on Latinos ${ }^{1}$ in the US at one historical juncture (the late 20th-early 21 st centuries) ${ }^{2}$ and examines their responses to questions of « race » on the US census. It also examines the theories developed to explain the "Some Other Race » (SOR) response chosen by many Latinos and chronicles government efforts to force Latinos into more traditional US race categories.

Perhaps, the most well-known example of the social construction of " race " is the experience of the Jews in Europe during World War II. A review of the evolution of categories in the US census also reflects how socially constructed " race » is. What's more changes in US census categories reflect the US's politicaleconomic and scientific milieu at particular points in time. In addition, what is called and measured as « race » in the US census is particularly unique within the larger world context. A historic emphasis on hypodescent (i.e., the one-drop rule) and the conceptual distinction between race and ethnicity are two characteristics 
that make « race » in the US distinct from many other countries (Davis 1991; Morning 2008).

In contrast to France, which does not collect "ethnic statistics 》 and where there is much division as to whether to collect such statistics (Amiraux and Simon 2006; Sabbagh 2009), the US has - from its inception - used race/ethnic categories to count its population. These categories have changed over time, but a basic structure of "white " and "not white " has persisted. Interestingly, although today we call these categories " race categories », that is not what they were originally called. There was a shift from the use of the word " color» (or colour in the early censuses) to "race ». Although in the 19th century the scientific discourse on "race " and "racial differences " was quite pronounced in the US and elsewhere ${ }^{3}$ the word " race » was not used as a census category label until the 20th century, when it appeared in the 1900 census (Rodríguez 2000).

Reflecting the importance of slavery to the US economy, when the US conducted its first constitutionally mandated decennial census in 1790, "Free Whites » were counted along with « Slaves ». Slaves are presumed to have been African or descendants of Africans. What is significant in the choice of the phrase " Free Whites " is that a color term was used for this category. Other terms, such as « free inhabitants » or " free people » might have been chosen then, but they were not. The use of the term " White » initiated what would become in subsequent censuses a more clearly labeled « racial » classification schema (Anderson 1988; Rodríguez 2000). There was also a third category, "All Other Free People » who are presumed to have been mixtures of Whites, the indigenous population and/or free people of color. Over time, the first two categories evolved into simply "Whites » and "Blacks ». The third category became, first, "All other free persons, except Indians not taxed » between 1800-1810 and, then, « Free colored persons » (1830-1840).

In 1850 , somewhat in response to the concern over the high degree of mixing taking place and the alleged inferiority of the off'spring of such Black and White mixing, mulattos were counted ${ }^{4}$. Consequently, the third separate category disappeared and Blacks were subdivided into Free and Slave Blacks and Free and Slave Mulattos. This categorization continued until the Civil War, when slavery was abolished and the categories that appeared in the 1870 census were merely Whites, Blacks, and Mulattos. Earlier, in response to the large number of immigrants arriving from Ireland and Germany, « Foreigners not naturalized » were counted from 1820 to 1840 . Other " race » categories were added as the groups increased in number and as concerns were raised about the large numbers entering the country, e.g., the Chinese (in 1870) and the Japanese category (in 1880), or as they were recognized and resettled, e.g., American Indians (in 1870) (Rodríguez 2000, chap. 4). In essence, the changes in categories have reflected changes in scientific thought, immigration and political and economic concerns, 
but a basic white and not-white racial dichotomy evolved and has prevailed in US census classifications.

With the arrival of larger numbers of Spanish-speaking people from Mexico, Central and South America and the Caribbean during the second half of the twentieth century, the question of how to count this group surfaced. The passage of a number of anti-discrimination legislative acts and the subsequentdevelopment of affirmative action programs in the 1960s-1970s accentuated the need to determine the numbers of people in disadvantaged groups. The honorable military service and deaths of many (mainly, at the time, Puerto Ricans and Mexicans) convinced legislators that they were deserving of assistance and that the degree of disadvantage that existed within these groups should be ascertained.

But how to count the groups? The US had evolved a somewhat color-coded race structure. There were Whites, Blacks, American Indians (red), and Asians (yellow). This was a heterogenous group that resulted from the same kind of migrations and mixing that had led to the US population. They also brought their own racial constructions, which were a result of their own unique population histories and political-ideological developments.

In 1980, a decision was made by the census bureau to consider them an ethnic group within which individuals could be of any race. This is still the basic census policy, but as we will see below, there has been a tension between this view and efforts to make the group into yet another «race»-occupying a perhaps « brown » category. Some would argue that this effort began with the attempt to place the Spanish origin population into one category, i.e., the Hispanic category in 1980 (see on this Oboler 1995). There was clearly precedent for this and it could be argued that the Spanish origin group was just as heterogenous as the groups now called "Black or African American » and "American Indian » had been. Yet, in the past the census had successfully subsumed widely varying nations, tribes and individuals into generic categories, e.g., "Indians » and " Blacks ». Eventually, many came to identify with, or, to accept these terms as applying to their group - although many also retained their own individual or group identity, e.g., as Mohawk or Navajo. These categorizations were also accepted, by and large, by those not in these categories. A similar result could be expected with the US census created category of « Hispanic ».

However, the categories used by governments to count populations are not always completely in synchronism with the categories used by the people being counted (Morning 2008, p. 259). Recent immigrants coming to the US from Europe or Africa often express surprise at being classified simply as « White » or « Black »-particularly if they have been minorities, or, if they had very distinct ethnic identities within their countries of origin, e.g., Albanians in Italy, the Yoruba in Nigeria, the Kurds in Iraq. State classifications may involve contestations over such categorizations. Or, there may be negotiations between state definitions and folk/popular understandings; or, between the dominant and the 
dominated. Haney López's review of the many court cases that individuals brought forth so that they (and the groups they represented) could be racially classified as « white » describes the numerous legal negotiations that have ensued during US history over racial classification (Haney López 1996). Perhaps the most significant example of such a negotiation is the historic 1894 Supreme Court case of Plessy vs. Ferguson, which is recognized as sanctioning the (separate and unequal) Jim Crow practices and laws in existence then. The plaintiff in the case was Homer Adolph Plessy, a Black man who argued that since he was $7 / 8$ th white, and that since he " looked white, » he should be allowed to sit in the white section of a train. Other cases contested the 1790 law which disallowed non-Whites from becoming naturalized citizens. Two significant cases are Ozawa vs. United States (1922) and Bhagat Singh Thind vs. US 261US204 (1923). Ozawa, a Japanese immigrant argued that because his skin was white, indeed whiter than that of many Caucasians, he should be classified as white. Bhagat Singh Thind, an Indian immigrant made the case that since science had found that Indians were Caucasian, he should be classified as white. These cases were brought before the courts because the plaintiffs wanted the same rights and advantages that Whites enjoyed. Few were successful; both of these plaintiffs lost.

\section{THE CHANGING DEMOGRAPHIC CONTEXT IN THE US}

Just as other cases of contestation are best understood when placed within their historical and structural context, the significance of Hispanic/Latinos responses to census questions on race is best understood in the context of race reporting in the US's current demographic milieu. Today, almost one of every three US residents is of non-European origin. Hispanics/Latinos are the largest minority group and census estimates showed them to be 14 percent of the nation's total population or 41.3 million as of July 1, 2004. However, this estimate does not include the 3.9 million residents of Puerto Rico, who are also US citizens and would raise the total to 45.2 million ${ }^{5}$. This would make the US population of Latinos larger than the population of Spain and the second-largest Spanishorigin population in the hemisphere, after Mexico (Thomas 2005, pp. 73-76).

The growth of this population since 1980 has also been dramatic. Hispanics/ Latinos grew more than seven times faster than the population of the nation as a whole, increasing by half, while the white (non-Hispanic) population increased by only 6 percent between 1980 and 1990 (US Bureau of the Census 1991, table 1; US Bureau of the Census 1993, p. 2). In the next decade, the Hispanic population increased 58 percent. The most recent figures show that between 2003 and 2004, one of every two people added to the nation's population was Hispanic ${ }^{6}$. Consequently, not only are Latinos a substantial part of the US population, but they account for half its population growth. 


\section{Race and ethnicity in the US census}

How particular groups are counted and classified often involves conflicts between state definitions and folk or popular understandings. Hence, and for example, persons may be classified "White " in the US, but may consider themselves Jewish or Islamic instead of White. Or, they may consider themselves not quite the same as " plain vanilla white », but perhaps Jewish and white. The same can be said for the other race groups in the US census, i.e., those classified as Black or African American may see themselves more as Yoruba or Jamaican; or, as Jamaican and Black.

This conflict or contest between state and folk understandings is universal. Chantal Caillavet refers to it, in her response to my paper, as « the divergence between the point of view of the passive "subjects", and those in power, or the dominant society in a given period » (Caillavet 2006). This divergence or contestation has grown as an issue along with the increasing migration of peoples around the world. The experience of Latinos in the US census provides insight into one such contestation.

The US census has used a variety of indicators as it has wrestled with the question of how to best count and categorize the group we now call Hispanic or Latino. For a period of time, the US Census Bureau used cultural indicators, such as whether the person's mother tongue was Spanish (1940), and whether they had a Spanish surname (1950) or were of « Spanish Origin » (1970). (In other words: language, surname and ancestry.) In 1930, the Census Bureau also included a separate category in the race question for one particular Latino group, i.e., the « Mexican » group. This category was eliminated in subsequent censuses. From 1940-1980, Puerto Ricans, Mexicans and all other Latinos were classified as "White » unless the census interviewer determined (or the respondent indicated to the interviewer) that they were some other race category, e.g., Black, Asian, etc.

The 1980 census marked a major turning point. This was when the US Census introduced - in response to political pressure from Hispanic organizations - what it called « the Hispanic Identifier » (Choldin 1986). This was a specific question, which asked all residents whether or not they were Hispanic. If the respondent said "Yes ", they then checked off one of four boxes, i.e., Mexican, Cuban, Puerto Rican, and other Hispanic (specify), to indicate what kind of Hispanic they were. So it was in 1980 that Hispanics were first counted on a national basis. (This same Hispanic identifier is still a part of the census and it is included in the " short form » that goes out to all residents ${ }^{7}$.) There is also a question on race that asks all people, Hispanic and non-Hispanic, to indicate their race. In the last 2000 census, the two questions appeared as appears in Figure 1.

In addition to including the Hispanic identifier, it was also in 1980 that the US census instituted its mail-back questionnaire system. In so doing, it altered the 
did not have a specific racial category. For example, Asian Indians, or « Hindus » as they were then all called - regardless of religion - were placed into this category at the turn of the 19th century. However, the category of " Other Race » was to change dramatically after the 1980 census, for millions of Latinos were to choose this category for the next three decennial censuses. In fact, various smaller; previous censuses (generally conducted by census enumerators) had indicated that Hispanics/Latinos were $90 \%$ white. After 1980, the official racial classification of Latinos changed dramatically. For the 1980, 1990 and 2000 censuses only about half of Latinos were to report themselves as white, and over $40 \%$ would choose the "Other Race » category in the last three nation-wide decennial censuses. In essence, since 1980, Hispanics/Latinos have responded to questions of race in starkly different terms than the non-Hispanic population in the US - in ways that have confounded census officials but also moved us to think about " race » in new ways.

Another major change in the way that the US counted its people is that in the year 2000, respondents were allowed to choose more than one race category. This altered the 200-year practice of the US census, which required that individuals choose only one race category. This « only one race " practice had reinforced and reflected the hypodescent (or one drop rule). Accordingly, persons who were of different (supposedly pure) races were to be classified socially and, in the census, as a member of the non-white race, regardless of physical appearance, cultural socialization, or personal identity preference. Interestingly, few Americans (2.4\%) chose more than one race. Hispanics/Latinos chose more than two categories two and a half times as often, but even this was only $6.3 \%$. What again loomed large were the $42.2 \%$ who chose the "Some Other Race» (SOR) category; many of whom also wrote in a Latino descriptor, such as Mexican, Chicano, Puerto Rican, Honduran in the specify portion of the race question(US Bureau of the Census 2001a, p. 10). This response contrasted vividly with the proportion - only $0.2 \%$ - of non-Hispanics who chose the same (SOR) category (US Bureau of the Census 2001b). Figure 2 indicates how the remainder of the Latino population answered the race question in the year 2000: $47.9 \%$ of Latinos indicated they were White, $2 \%$ reported they were Black, $1.2 \%$ said they were American Indian, and less than $1 \%$ said they were Asian, Native Hawaiian, or Other Pacific Islander.

The tendency of a large portion of Latinos to choose the "other race" category and to write in Latino descriptors has been a consistent pattern for the last three decennial censuses. In both the 1980 and 1990 censuses, about $40 \%$ of Latinos in the country chose this category (Denton and Massey 1989; Tienda and Ortiz 1986; Martin et al. 1990; Rodríguez 1990, 1991, 1991a, 1991b). Latinos' SOR response has continued despite various attempts on the part of the US census to dissuade the « Other Race » response. For example, the census inserted the word « race » into the race question numerous times, reversed the questions, 


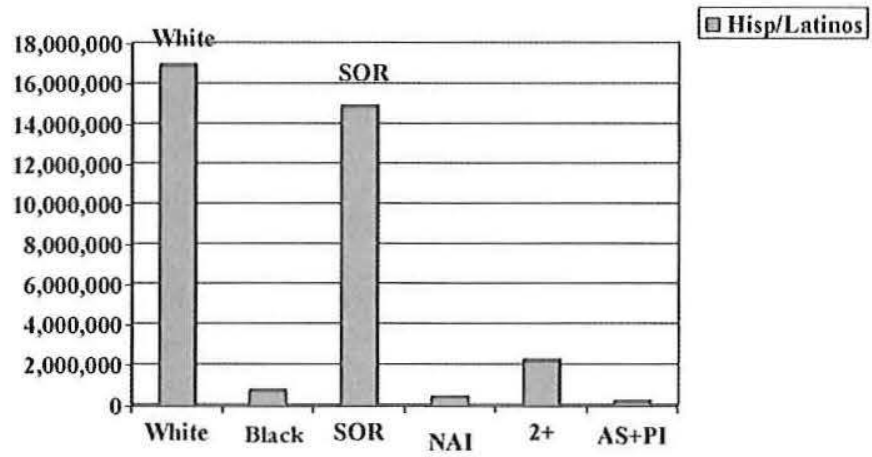

FIG. 2 - Hispanic/Latino population by race, census 2000.

so that the Hispanic origin question would precede the race question, and in the 2000 census, added the word "Some " to the "Other race " category in an attempt to make clear that the race question was calling for a race response and not a national origin or Latino descriptor. Even the decision to allow respondents to choose more than one race category was an attempt to dissuade Latinos from choosing the Other Race category (Padilla 2001). In fact, the proportion and numbers of Latinos choosing SOR has grown significantly (Guzmán and Diaz McConnell 2002) and was estimated in 2004 to be over 19 million people. The problem with the SOR response, from the government and statistician's perspective, is that it is not possible to arbitrarily place those in the SOR group into the traditional US racial categories of white, black, etc.

\section{POINTS OF CLARIFICATION}

Before proceeding to an examination of why Latino responses to the race question are so different from that of non-Latinos, it is perhaps important to make a few points of clarification for those less familiar with Latinos in the US and with how race and ethnic data are used in the US.

\section{Use of race and ethic data}

First, it is important to clarify that the race and ethnic data are very significant and are relied upon by a variety of users in the US. For example, they are used by governmental and non-governmental agencies to implement civil rights legislation, anti-discrimination policies, health planning, research and operations. The private sector also uses the data to estimate demand for products and services and to locate facilities. Non-profit organizations use the data to gain information, 
develop proposals, and advocate for the groups they represent or seek to serve. Finally, academics and journalists use the data for basic and policy-related research and to frame issues of interest to the public and to describe the " face » of the population.

\section{Latinos and socioeconomic status in the US}

It is also important to note, for those unfamiliar with the US context that, although there are still unresolved questions on how " race » or color operate among Latinos, a number of studies have found substantial socioeconomic (SES) differences by race among Latinos. In general, studies have found that Latinos who report that they are Black (or who are seen as « dark ») are more residentially segregated and have lower SES outcomes than their White Hispanic counterparts ${ }^{11}$. Although other variables have also influenced SES (e.g., the labor markets faced by different groups of Latinos), this " color cost » has been observed for some time ${ }^{12}$.

\section{The heterogeneity of the Hispanic/Latino populations}

The terms Latino or Hispanic may obscure for some the actual heterogeneity that the term represents ${ }^{13}$. The Latino/Hispanic group is composed of a variety of Latino national origin groups. Figures $3 a$ and $3 b$ show what this medley looked like in 2000, with and without the inclusion of the residents of Puerto Rico, who are US citizens ${ }^{14}$. As the figure indicates, Latinos of Mexican origin constituted the majority, Puerto Ricans the second largest single group, followed by Cubans. All other Latinos/Hispanics (i.e., from different national origins) combined constituted $26-28 \%$ of the total. Despite this diversity of national origins, all Latino groups chose the SOR response to a much greater degree than did non-Latinos. For example, in the 1990 census, while only $12 \%$ of Cubans chose this category, $47 \%$ of Mexicans and $59 \%$ of Salvadorans did so (Rodríguez 2000, p. 9). More recent studies also showed similar differentials in reporting by Hispanic national origin, see, e.g., US Dept. of Labor, Bureau of Labor Statistics (1995, p. 4), Tucker et al. (1996, p. 45), and Saenz (2004). Such differentials between Latino national origin groups pale, however, when compared to the difference between Latinos and non-Latinos. As will be recalled, in 2000 , less than $1 \%$ of non-Latinos chose SOR as compared with $42 \%$ of Latinos. Adding to the diversity of this population is that each group is also physically quite diverse, reflecting - as does the US population - the migrations and blending of peoples from all continents, plus the indigenous groups. 


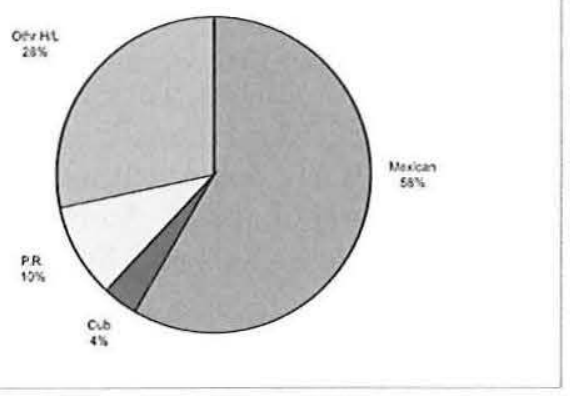

FIG. 3a. - US Hispanics, 2000.

(source : US bureau of the census, 2001)

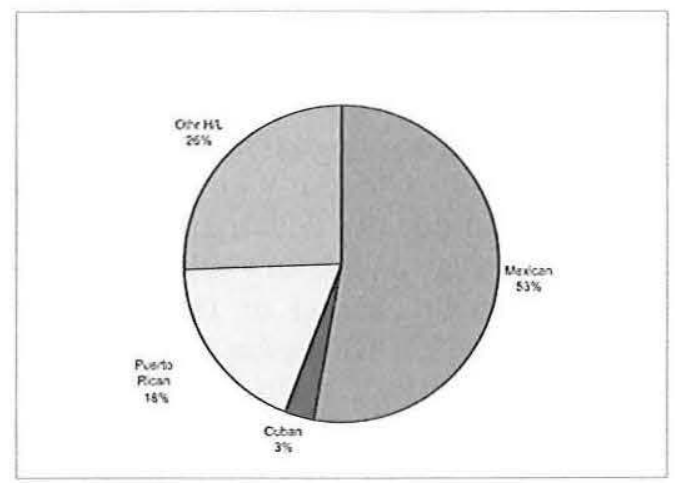

FIG. 3b. - US Hispanics, Puerto Rico included, 2000.

\section{THEORIES, INTERPRETATIONS AND ASSUMPTIONS}

Let us turn now to research and interpretations that have been advanced to explain why so many Latinos chose the "Some Other Race » response in the census ${ }^{15}$. These include the mixture and confusion assumptions; the theory that Latinos have a different understanding of race, which has developed in Latin America; the denial of race; examinations of how contexts influence responses; and the racialization and non-assimilation hypotheses.

\section{" Mixed or multiracial » and " mixed up or confused »}

An initial explanation of the Latino SOR response was to assume that Latinos were indicating that they were of "mixed race» or multiracial (see Gonzales and Rodríguez 2004; Rodríguez 1992). However, when given the option to choose more than one race category in the 2000 census, only 6.3 percent of Latinos did so and most of these indicated that they were « White » and " Some Other Race » and many specified a national origin in the second category. In light of little mainstream research in the area, another of the early explanations offered for " the other race " departure of Latinos was the assumption that Hispanics had misunderstood or had difficulty with the question (see McKenney and Bennett 1994, p. 21; McKenney and Cresce 1993, pp. 173-222; Scarr 1994, p. 9; McKenney, Bennett et al. 1993; Buehler et al. 1989, p. 458; Rodríguez 1991a, pp. 77-78). Misunderstanding of the question undoubtedly accounted for some responses, but it is doubtful that it accounted for all $40 \%$ of respondents. 


\section{"Spanish race 》 and " race 》 in the US}

Another view contends that it is possible that respondents may have interpreted the question within their own frame of reference, which may be a different frame of reference than that generally used in the US ${ }^{16}$. Indeed, Hirschman, Alba and Farley (2000, p. 388) indicate that: « Many Hispanics, especially immigrants, are unsure how to respond to census questions on race because the North American concept of race is not established so firmly in Latin American cultures ». This implies that there are dual constructions of race, i.e., "Spanish race " and " race » in the US.

Caillavet's (2006) comments provide some insight into how racial/ethnic distinctions evolved in the Northern Andes of Latin America. Her comments are based upon the historical studies of Andean societies (especially Ecuador and Colombia) that she has conducted. She examined the changes in race, ethnic and census categories that occurred there during the colonial period and how they reflect the political structures of their times. She finds, for example, that where the dominated population is primarily autoch thonous or indigenous and « the dominant population has an external origin, and it is, demographically, in a small minority ", - a situation very typical of the Northern Andes areas then - the dominant elite class « will continue to justify and exercise its domination by accentuating ethnic difference in the most visible and external way, introducing racial classification, and creating hierarchies of these phenotypes » (Caillavet 2006 , p. 2). The ways in which these ethnic lines were accentuated include the insistence on the Indians' wearing standardized clothing of « manta y camiseta » and keeping their hair long - regardless of the variety of hair styles they'd had before the Spanish conquista, which were many. Also, accentuating boundary differences between groups were the prohibitions against any kind of head dress, a ban on body paintings, and hairstyles and head adornments. These requirements placed them in contrast to the varied dress, hairstyles, adornments and short hair of the dominant group and accentuated phenotypic differences. Interestingly, at this point, the mestizos (which included every type of mixture) were aligned with the Spanish or white category. This kept the indigenous race " pure. » The pure indigenous were forced to pay taxes or supply labor. Those who were not classified as indigenous were not subject to these requirements but had other tasks.

Curiously, Caillavet (2006) finds that, during this same period, Spain followed a different strategy to govern the dominated. Here, the Jews and Muslims, who had not been expelled, were obligated to downplay differences. For example, in contrast to their former cultural practices, they were now forced to have beards and to wash themselves less often - thereby, discarding the Muslim cultural practice of bathing in public bath houses. She also notes that in both areas, there was continual evolution of categories and changes within categories. For example, 
in Quito, Ecuador, the category of « Mestizo » was not separated from that of "White » in the late eighteenth century censuses, but it does appear as a separate category in the nineteenth century when the Republic takes control. In addition, Caillavet (2006, p. 3) adds that the understanding of what formal categories meant often varied. So that although Whites and Mestizos might have been placed in the same category, the reality was that there was a growing separation between the white aristocracy and the Mestizos, which included Mulattos and lighter-skinned " Montañeses ». Also a minority of low-income Whites might be referred to " pejoratively » as mestizo in one area, while a stable, rural Mestizo population in another area was classified as white. Lastly, she points out that within these classifications, individuals negotiated or sought out the most advantageous type of classification - and that this did not seem to be particularly problematic ${ }^{17}$. Caillavet (2006) notes that this had been a common practice in the Ancien Régime in Europe, where individuals moved from one part of the country to another (or from the Old World to the New World) and left their earlier identities and histories behind, changing their names, religions, often pursuing different occupations and sometimes becoming landholders instead of being landless peasants. Women, of course, did this regularly and in a sanctioned way when they married, changed their name, and migrated to the other areas.

Both of these strategies for dealing with the dominated are in contrast to those developed in the US. In the US, a different approach was taken to ensure that this dominant group retained dominance. This involved creating and/or reinforcing the idea of the " purity » of the white race. The " white " group came to be defined as a group, which had no " black blood » (or, in many cases, any non-white). Although we know now that blood is blood, historically in the US any type of mixture was deemed non-white and this off-spring viewed as nonwhite. Consequently, if it was found that a person had " one-drop » of black blood, they and their children could never be white - while in Latin America " whitening » occurred over time. In the US « passing " as White occurred but when discovered often had serious and negative legal and social consequences. This idea of hypodescent kept the dominant group " pure » and prevented others (not of this group) from becoming a part of it. Separate schools, churches, residences, etc. helped to develop, perpetuate and reinforce group boundaries between the dominated and the dominant. New immigrants coming to the US entered into their respective queues, based on this white/not white division.

Accordingly, we can note some basic, broad differences between racial constructions in the US and in Latin America. In the United States, rules of hypodescent and categories based on presumed genealogical-biological criteria have dominated thinking about race. Racial categories have been few, discrete, and mutually exclusive, with color, hypodescent or knowledge of African ancestry playing important roles. Categories for mixtures, e.g., mulatto, have been important at times, but ultimately transitory. In contrast, in Latin America, racial 
constructions have tended to be more fluid and based on many variables, like social class and phenotype. There have also been many, often overlapping categories, and mixtures have been more consistently acknowledged and have had their own terminology. While in the US, those with « one-drop » of « black blood " could never become white, in Latin America, "whitening " occurred over generations, and, on some occasions, within one generation, e.g., when an individual acquired greater wealth or status. Unfortunately, the whitening process also tended to include the depreciation of indigenous or African ancestries. It is argued that these general differences are what many Latinos bring into the US, and they strongly determine how they view their own " identity » and that of others - and that this is reflected in their responses to the questions of race.

This perspective that Latinos view race differently, i.e., that their folk view is different from the US state view, has recently received more attention. There does appear to be some evidence for a different understanding of what race is; or, that the Spanish term " raza » is not exactly equivalent to the English term " race » - at least as understood in the US. It may be that for Latinos the concept of " race " is less influenced by hypodescent or blood quantum (as is the case in the US) and more influenced by other variables such as class, culture, appearance, education, national origin, ethnicity, or nationality; or; a combination of these and skin color (see Bates et al. 1994, p. 109; Rodríguez 1991a, 1992; Rodríguez and Cordero Guzmán 1992; US Oflice of Management and Budget 1995, p. 44689).

In essence, within this view, many of the individuals who chose the " Other Race » category on the census forms and wrote in a Latino referent saw themselves as members of a group that had its separate ethnicity and saw that ethnicity as independent of the other social and "racial " categories listed in the race question. In other words, they were " una raza diferente » but this was not equivalent to a separate race as defined within the US race classification system. The Latino referents, which were written in, e.g., as Hispanic, Latinos, Mexicans, etc., indicated this. Many Latinos placed themselves in a category that said they "were none of the above ", i.e., the SOR category. However, research in this area indicates that, on further probing, some Latinos who choose SOR may also acknowledge that their phenotype or color would place them in the other categories, e.g., as White, Black, American Indian, and that others might place them there (Rodríguez 2000).

But does this mean that there is one Latino view of race to which all Latinos subscribe? Apparently not. Not all Latinos responded that they were « Some Other Race » on the census. Only $47 \%$ of all Latinos said they were SOR, others reported that they were just white, black, etc. Moreover, there are different views of race within different countries, classes, and even families. Latin Americans' views of race are dependent on a complex array of factors, one of which is the 
racial formation process in their countries of origin (see on this, Safa 1998). There are also other variables that influence individuals' views of race, e.g., class, racial phenotypes within families, and educational experiences.

In addition, " race " as understood by many Latinos is not without its own racism, colorism, and other biases; it too is based on historical social constructions that involve slavery, conquest and colonialist regimes (Rodríguez 2000, chap. 6). Nor, does it mean that «Spanish race » views are devoid of implications of power and privilege - both among Latinos in Latin America and in the United States (see Torres and Whitten 1998; Martínez-Echazábal 1998).

With regard to the future, some authors have written on the increasing convergence of racial constructions in the US and in Latin America. However, it is unclear whether the US is becoming more like Latin America and masking its own racism as Hernandez (2002) and Bonilla-Silva (2003) maintain; or, whether Latin America is becoming more like the US. In the latter perspective, US views and race questions are becoming part of Latin America, especially via the educational training or experience of Latin American elites; research exchanges and projects funded by US foundations and other institutions in Latin America. Also influencing such change is research carried out by North American scholars, who apply US-based paradigms and interpretations to their research conclusions; these, in turn, serve to educate new generations of younger scholars, both in the US and Latin America. Echoes of this debate can be heard in the literature on Brazil (see e.g., Harris et al. 1993; Telles 1995; Bailey 2002, 2008). What is clear is that « race » is indeed changing in both hemispheres and that with greater time in the US Latino's racial and ethnic identities will also change.

\section{Denial of race}

Another perspective that, to some extent, challenges the Spanish race view, interprets the choosing of the "some other race " category as reflecting a denial of race, or, a disinclination to identify as "Black » or " Indian ». In other words, and for example, that by not checking traditional US race categories, Latinos evade their racial designation as Black - and being non-white or black is a reality in countries dominated by Whites. But not much empirical research has been done on this (see, however, Rodríguez and Cordero Guzmán 1992; Itzigsohn, Giorguli and Vazquez 2005; Román 2001). More recently, Morning (2008, p. 255) has proposed that the fact that the US census has two questions, one measuring ethnicity and the other measuring race, unwittingly supports the «long standing belief that race reflects biological difference and ethnicity stems from cultural differences $»$. This conceptual distinction, which is reflected on the census form, may induce those of Spanish origin to choose the SOR category and write in national origins. It may also induce others, e.g., many Haitians, who view ethnicity, national origin and race to be somewhat synony- 
mous terms, and whose groups do not specifically appear on the census form, to choose SOR.

\section{CONTEXTUAL INFLUENCES}

The question of how " context » influences Latinos' racial responses is one area that has benefited from solid and ample empirical research. It is, however, also a complex area because it involves defining " context » in a myriad of ways. For example, there is the micro context, which includes, for instance, the context that the question presents to the respondent. There is also the macro context, which is the larger context within which the person was raised or resides. The following sections cover first research in the micro contexts and then various approaches that take a more macro view.

The micro context is the context in which the question is asked and its format. Depending on question context, Latino responses to race questions are more variable than the more consistent responses of Whites, African Americans and Asians, who respond similarly regardless of how the question is asked. This reflects the extent to which many Latino responses are contextually influenced. Variables that affect Latino responses to the race question on the micro level include: who asks the question; who answers the question; how and where the question is asked, i.e., is there an Anglo interviewer, a Hispanic category as a possible choice, the presence of other cultural groups as categories; and, the phrasing, structure, placement, format and purpose of the questions (see Rodríguez 2000, chap. 7; Tafoya 2004; Chevan 1990; Ramirez 2005; Hirschman, Alba and Farley 2000, p. 388; Landale and Oropeza 2002; Rodríguez and Cordero Guzmán 1992; Itzigsohn, Giorguli and Vazquez 2005).

\section{The local context: place and neighbor matter}

A few researchers have found that place - or the local context - matters in determining how Latinos answer questions about race. For example, Itzigsohn, Giorguli and Vazquez (2005) found that, despite similar socioeconomic profiles, the Dominicans in Providence were more likely to choose the term " Hispano » than those in Washington Heights who chose " Black » more often. They maintain that this is related to the greater number, presence and salience of Blacks in NYC (23.6\% in the 2000 census) as compared with Providence $(7.5 \%)$. They also cite Logan (2004) who, examining national data, asserts that the greater the proportion of Blacks in an area, the greater the proportion of Latinos who report on the census that they are Black. Rodríguez (1990) examining earlier 1980 census data on the racial identification of Hispanics by state also found that the greater the proportion of Blacks in a state, the lower the proportion of Hispanics who 
chose the "Some Other Race » option. She speculated that the more salient the biracial structure, i.e., the greater the proportion of Blacks and Whites, the more likely Hispanics were to accept biracial classification for themselves as White or Black ${ }^{18}$.

Logan (2004) contends that Latino racial identification is the result of people's identities being affected by the social and cultural milieu in which they live. He says that intermarriage, everyday encounters with racial identification by others, and the strong presence of African American and black diasporic culture in NY influence many Dominicans to identify as Black (see also Itzigsohn, Giorguli and Vazquez 2005). Another context that appears to influence Latino racial reporting is the educational context and the race and ethnicity of fellow students (on this see, Vaquera and Kao 2006; Vaquera and Doyle 2005; Harris and Sim 2002; Eschbach and Gomez 1998).

\section{Migration and changes in contexts}

Some authors have argued that with migration to the United States, conceptions of ethnic, racial and national identities are often called into question and identities become « a terrain of ideological contestation » (Omi and Winant 1995; Duany 1998, p. 149; Foner 1998; Torres-Saillant 1998; Oboler 1995). Some observers ask whether the Latino write-ins, reflecting national origin, etc. in SOR reflect the ideological contestation to which the authors above allude (see McKenney and Bennett 1994). These results suggest that when individuals migrate from their home countries to the US, they enter a different racial structure. This experience was early noted by the anthropologist Wagley (1965), who described how a man's racial classification could change when traveling from the Caribbean, where he would be white, to Mexico, where he might be described as mulatto, to the US, where he was negro or black ${ }^{19}$.

\section{The racialization context: histories and discrimination}

Although the process of racialization and discrimination can also be thought of as conjoined contextual factors, they are discussed separately here. In the Itzigsohn, Giorguli and Vazquez (2005) study on Dominicans, the authors concluded that the experience and perception of racial discrimination - whether in the US or in their home countries - played an important role in racial self-classification. They found that only those who identified as « white " reported little discrimination against Dominicans. However, Dominicans who identified as black or " hispano " had a more negative view of US and Dominican relations, reported greater discriminatory experiences and believed that Dominicans were discriminated against in the US. In contrast, Dominicans who identified as « indio » (Indian) had more positive views of US and Dominican relations 
than those who identified as black. The authors contend that identifying as " indio » is another way of distancing one's self from blackness and that this distancing has historical roots in the Dominican Republic. They also note that West Indian and African immigrants have confronted similar tensions between racial and ethnic identity - suggesting other instances of contestation over US classifications.

\section{Racialization and non-assimilation}

Is the Latino SOR response to the race question a refusal to assimilate or to accept racial categories and become Americans? Does the discrimination experienced within the US social context play a fundamental role in choosing SOR? Golash-Boza (2006) addresses the question more generally when she asks if the experience of discrimination affects whether individuals identify as " American » or in ethnic terms. She finds that Hispanics who experienced discrimination were more likely to adopt pan-ethnic terms such as Hispanic or Latino, as opposed to the term American. She also found that the use of pan-ethnic terms had grown substantially during the 12 years period she studied, from $39 \%$ in 1989 to $81 \%$ in $2002^{20}$. She also found that darker skinned Hispanics were also more likely to adopt or retain their national origin identifier as opposed to an American identifier (see also Bonilla-Silva 2003, Vaquera and Kao 2005 on this).

\section{THE MANY INFLUENCES}

In summary, for many Latinos, responses to questions of race are seldom the simple, straightforward affairs that they tend to be for most non-Hispanic Whites (Rodríguez et al. 1991) ${ }^{21}$. Indeed, what the current and limited research seems to indicate is the complexity of race for Latinos in the United States. Latinos' views of race appear to be influenced by a complex array of factors. These include the racial formation process in countries of origin, class status, exposure to US educational systems, phenotype and perception of phenotype by North Americans, phenotypic variation within their family, language, age and/or generational status, experiences of discrimination and racialization, and education. They also include social variables, such as significant experiences in schools, jobs, and social settings, neighborhood socialization and the racial composition where they live. Case studies in the literature also indicate that there is change over time with regard to how Latinos respond to questions of race (Rodríguez et al. 1991). Each of the above needs further investigation and all probably account to some degree for the SOR response and many interface with one another. However, much more research is needed to determine whether some of these explanations apply more to one Latino group than to another. 
What is evident is what Véran (2006) and Landale and Oropeza (2002) have noted and that is that the construction of a racial and ethnic identity is an ongoing process that involves negotiation between an individual and others (see also Omi and Winant 1995; Portes and Rumbaut 2001; Rodríguez and Cordero Guzmán 1992; Rodríguez 2000; Waters 1999). Self-definitions shift over time and across social contexts. This negotiation (and perhaps contestation) is reflected in Latinos' SOR response.

As Véran (2006, p. 1) notes, the SOR response « questions the interaction between social, political and analytical categorizations ». In essence, many Latinos (over $40 \%$ ) do not consider themselves part of the structure of signification. Socially and politically, they do not organize themselves as White Latinos, although some do organize and identify as Afro Latinos, and some new immigrants also identify as Native American Indian. Analytically, the SOR response can be seen as a challenge to the way in which the Census and other social scientists construct categories. This negotiation is at work in France and increasingly in other countries that have received immigrants from former colonies, or, from culturally and physically distant shores. What the outcome of these negotiations will be are unclear in both France and the US. According to Véran (2006, p. 2) in both France's " political fiction " where racial categorization is forbidden and in the US's more supposedly pragmatic framework, social groups are challenging the structures of signification and questioning « the political meanings and uses of racial categories $"$.

But, according to Véran, from the French racial fiction perspective, Latinos' SOR choice raises a number of questions for all theorists. Among them are " what is the meaning of race? ». Is it possible to exempt biology from analytical categorization? Or, is ethnicity to race what gender is to sex? How can the categories in the US census be adapted so as to better reflect the views of Latinos? And, lastly, if so many reject the classic categories, as the SOR response indicates, do we still need to classify people racially? Would it be best to use ethnic designators for all - as Morning (2008) recommends? ${ }^{22}$ As plans for the US's 2010 census move along, it does not appear that "race » will be dropped - although as the section below will indicate, there have been many attempts to discourage the SOR response and to increase Latino reporting in the traditional White, Black, etc. categories. Moreover, new research in this area indicates that many are investigating the "racialization of Latinos in the US ». This suggests that the pressures to assimilate or adapt to the current race-color based structures are quite strong. It may be, that - for the time being - Véran's $(2006$, p. 4) quote of Adriene Rich [1974] still reflects the current situation: " this is the oppressor's language, yet I need it to talk to you ").

There is an intense but multifaceted questioning occurring within French " cultures of scholarship » and in public debate over whether to enumerate the population using ethnic statistics (Amiraux and Simon 2006). On the one hand, 
such categories may enable the government in France to investigate and pursue (more aggressively?) anti-discrimination measures which would ensure that all of its inhabitants receive proper and adequate social treatment. On the other hand, the creation of such categories are seen by some leading to the reification of mutual group boundaries and assisting in the boundary marking process. In addition, some question whether this is the role of the state. In some ways, the emphasis on integration is similar to the emphasis that social scientists had on assimilation when writing about ethnic groups and immigrants in the early and mid 20th century US. The question of course is whether group boundaries and discrimination already exist, but are just not recognized by the state. This analysis of Latinos in the US suggests that if France decides to undertake enumeration by ethnicity, it will have to think hard about how the groups they seek to count identify themselves and if this is congruent with how they are identified by others or the state.

\section{STATE ATTEMPTS TO ALTER THE SOR RESPONSE}

The government's response to Latinos' " other race » reporting reflects negotiation or contestation between state and popular understandings; or; to use Caillavet's (2006) phrasing, it reflects the dominant's attempts to classify the dominated. In brief, the state addressed the SOR responses in the 1980 census results by changing the format of the question. For example, the Hispanic origin question was placed before the race question and the term "race » was inserted numerous times in the question so that Latinos would understand that they were being asked their " race » and not their national origin. But thisdid not diminish the number of Latinos who chose SOR; actually the proportion went up.

In the 1990 census, when the SOR responses were repeated, the government began a major re-examination of racial and ethnic standards and it tested numerous proposals (Evinger 1996). One proposal that was advanced was to "make Hispanics a race » in the next 2000 census. (This proposal was not advanced or enthusiastically endorsed by any Hispanic group.) This proposal was subsequently given a less inflammatory name, i.e., the " combined question format ». In this proposal Hispanics were to be listed as a race category along with the other traditional race categories, i.e., White, Black, etc. Essentially, Hispanics were no longer to be an ethnic group; they were to be a race ${ }^{23}$.

The Office of Management and Budget tested the "combined format » proposal but, when the studies found that using the combined format resulted in fewer Hispanics and Whites being counted, the proposal was abandoned (US Dept. of Labor, Bureau of Labor Statistics 1995, Table 1). Consequently, both the 
Hispanic question and the race question were continued on the census and the policy of the 2000 census continued to be that Hispanics were an ethnic group that could be of any race. As noted earlier; the decision of the census to allow respondents to " choose more than one race " was also an attempt to minimize the number who would mark « other » (Padilla 2001) ${ }^{24}$.

In preparing for the 2010 census, the US Census considered another approach to « correct » the Latino responses. It conducted extensive, nation-wide testing of the race question - without the SOR category. However, this ignited « a furious debate among Hispanic advocacy groups, statisticians and officials over how the nation's largest minority group should be defined racially ». In November 2004, Congressman José E. Serrano (D-NY) effectively cut the funding for any other projects that would eliminate the SOR category. As the New York Times subsequently noted, "Census officials had hoped to eliminate the "some other race" category from the 2010 questionnaire to encourage Hispanics to choose from among five standard racial categories », i.e., white, black, Asian, American Indian or Alaska native, and Pacific Islanders or Hawaiian natives (Swarns 2004a, 2004b).

But as the press release from Congressman Serrano's office stated Americans would not now be « forced to racially self-identify in a way they are uncomfortable with " and that this would produce census results that better reflected the realities of race in America today (Serrano 2004). Serrano also noted that eliminating SOR would ignore the evolving views of race across the country as immigration from Latin America has surged (Swarns 2004b). In essence, the Bureau had lost in its attempt to impose a racial classification system over the objections of the group that would have been most affected. As of this writing, the 2010 census will retain the "Some Other Race » category ${ }^{25}$.

In conclusion, the contest over how Latinos are to be counted was (and is still) an essentially silent, but intensely political confrontation. As noted above, Véran (2006) sees Latinos' SOR response as challenging the structure of signification. However, the SOR response is not necessarily a consciously political act. Many Latinos simply fill out the forms to the best of their ability. Most are not acting in a defiant or confrontational manner when doing so. However, because of different racial formation processes, their views are not necessarily congruent with those of the government. This is not a singular or new experience. As noted above, the historical record is replete with many other examples of groups that have undergone similar racializing and that have responded with their own racial constructions, re-constructions, and challenges to how they are classified (see Haney Lopez 1996; Rodríguez 2000, chap. 2; Coates 2006). Undoubtedly, Native American Indian groups had experiences similar to those noted above. Their collective experience illustrates that « race » and, in particular; racial classifications, have changed over time and have been very much influenced by political- 
economic factors, individual perceptions, and the intellectual scientific milieu of the times. *

* Manuscrit reçu en septembre 2007, accepté pour publication en janvier 2009.

\section{NoTES}

1. In these pages, the word Latinos is used too frequently to italicize it systematically.

2. Both terms, Latino and Hispanic, are used interchangeably to refer to the same population.

3. However, US census studies and reports did use the term " race» as well as racializing language. For more on the historical development of racial taxonomies, see Gould (1981), Gossett (1963), Jordan (1968), Stanton (1960) and Sanjek (1994).

4. Mulattos were only enumerated between 1850 and 1920.

5. Data on the most recent estimates of the Latino population are from http://www.census. gov/Press-Release/www/releases/archives/population/005164.html and http://www.census.gov/PressRelease/www/releases/archives/population/003153.html.

6. Cited in http://www.census.gov/Press-Release/www/releases/archives/population/005164.html.

7. It is perhaps important to note for those unfamiliar with the census changes in the US that the introduction of the Hispanic identifier fundamentally altered the whole racial classification schema of census population categories. Before the US introduced its Hispanic question in 1980 on the decennial census, all peoples were neatly folded into four large, obliquely color-coded categories of White, Black, Asian and Pacific Islander, and Native American Indian « race » categories. A few miscellaneous persons were to be found in the Other Race category - specifically, less than $2 \%$ in 1970. In 1980, each of these categories had to be re-named. The White category became the non-Hispanic White category, the Black category, the non-Hispanic Black category and so on. Hispanics, reported in all the racecategories, had to be subtracted from these categories to derive the " pure » race categories plus a Hispanic category. In 2000 , this all became more complex as people were allowed to choose more than one race category. Sixtythree races, or 6 single races (these included White, Black, Asian, Pacific Islander, Native American Indian, and Some Other Race) and 15 possible combinations were noted. When divided by whether these groups were Hispanic or not Hispanic, a total of 126 were arrived at (Porter 2001). Although few reports utilize all of these categories, they indicate the impact of these shifts.

8. This has changed somewhat. While in its prior years of census taking, racial determinations may have involved respondents to some degree, it was in 1980 that individuals would be asked to indicate their race without an interviewer present on mail-back questionnaires.

9. In response to the question, « What is race? », the US Census today responds as follows: « The US Census Bureau complies with the Office of Management and Budget's standards for maintaining, collecting, and presenting data on race, which were revised in October 1997. They generally reflect a social definition of race recognized in this country. They do not conform to any biological, anthropological, or genetic criteria ", www.census.gov, accessed July 9, 2008 (author'sitalics).

10. In the year 2000 census, the term « Some » was added to the Other Race category.

11. On housing segregation, see Rosenbaum(1996), Denton and Massey (1989), Massey and Denton (1993, pp. 113f) and the following on SES outcomes: Katzman (1968), Relethford et al. (1983), Arce et al. (1987), Murguía and Telles (1996), Rodríguez (1990; 1991a), Gomez (2000), Allen et al. (2000), Espino and Franz (2002, p. 612), Tafoya (2004). See also the debate between Telles and Murguia (1990) and Bohara and Davila (1992).

12. See, for example, historical references to this among Puerto Ricans in New York City in Rodríguez(1996).

13. SeeDiaz McConnell and Delgado-Romero(2004) who argue that a pan-Latino identity is real for some, but may also be influenced by methodological issues. 
14. Puerto Ricans in Puerto Rico are generally not included in tabulations or discussions about Latinos in the US. However, their inclusion alters the size and relative proportion of all Latino groups. For further analysis of this issue, see Rodriguez (1994). Some recent analyses have begun to include data from Puerto Rico.

15. This tendency to choose non-traditional or national origin categories is also evident in other data sets, e.g., one recent sample of 2929 Latinos in the US found that the majority of Hispanics surveyed preferred to indicate « Hispanic » or « Latino » as their race (Suro and Tafoya 2004). See also Landale and Oropeza (2002, p. 251), Vaquera and Kao(2005, p. 7).

16. Many other foreign-born persons also had difficulty reporting in the race item (McKenney and Bennett 1994,p. 22). See Rodriguez (2000, chap. 7) for other research in this area.

17. As noted earlier, individuals in the US also sought out a more advantageous type of classification, but they were not successful.

18. Rodriguez (1990) also found that, conversely, the greater the proportion of Hispanics, the greater the proportion that chose the Other Race category. The proportion identifying as Other Race varied greatly at the time, ranging from $6 \%$ in IV. Va. to $48.5 \%$ in Kansas.

19. It is of interest in this regard that in the 2000 census of Puerto Ricans in Puerto Rico, $81 \%$ of Puerto Ricans reported they were « White, " while only $47.4 \%$ of Puerto Ricans in the 50 states and Washington, DC, reported similarly on the same questionnaire. Also, only $9 \%$ indicated they were SOR in Puerto Rico in contrast to $47 \%$ in the states (see Christenson 2003; Denton and Villarrubia 2007).

20. This was the 2002 National Survey of Latinos, which was conducted by the Pew Hispanic Center and the Kaiser Family Foundation in 2002.

21. However, Latinos are not the only groups to have (or have had) complex and changing (or situational) racial/ethnic identities. See Thompson and Sanders (2001) who find that, among African Americans, there are a number of elements that are critical to identifying racially and to having a sense of belonging to a group.

22. For example, Great Britain uses « ethnic group » with a Mestizo category; South Africa « ethnic origin » with a Mestizo category. They do not use « race ». However, the use of the term « mestizo » still suggests a racial component to the classification.

23. Some in the data gathering community, who were in favor of the proposal, argued that adding Hispanics to the race question would reinforce the view that race is a social construction and not a biological reality. However, the question was still referred to as the « race " question.

24. Publicly and prior to this, the mixed race political movement appeared to be solely responsible for this shift.

25. An expanded discussion of the government's attempts to delimit the SOR response can be found in Rodriguez (2009).

\section{REFERENCES CITED}

\section{Allen Walter, Edward Telles and Margaret Hunter}

2000 «Skin color, income and education: a comparison of African Americans and Mexican Americans ", National Journal of Sociology, 12 (1), pp. 130-180.

Amiraux Valérie and Patrick Simon

2006 "There are no minorities here: cultures of scholarship and public debate on immigrants and integration in France ", Internatinal Journal of Comparative Sociology, 47 (3-4), pp. 191-215. 
ANDERson Margo J.

1988 The American census: a social history, Yale University Press, New Haven.

Arce Carlos H., Edward Murguía and William PArker Frisbie

1987 "Phenotype and life chances among Chicanos », Hispanic Journal of Behavioral Sciences, 9 (1), pp. 19-32.

BAILEY Stanley R.

2002 "The race construct and public opinion: understanding Brazilian beliefs about racial inequality and their determinants ", American Journal of Sociology, 108 (2), pp. 406-439.

2008 «Unmixing for race-making in Brazil », American Journal of Sociology, 114 (3), pp. 577-614.

Bates Nancy A., Manuel de la Puente, Theresa J. DeMaio and Elizabeth A. Martin

1994 Research on race and ethnicity: results from questionnaire design tests, paper presented at the Census Bureau's 1994 Annual Research Conference, March 20-23, American Statistical Association, Alexandria, Virginie.

BoHARA Alok K. and Alberto DaviLA

1992 "A reassessment of the phenotypic discrimination and income differences among Mexican Americans ", Social Science Quarterly, 73 (1), pp. 114-119.

Bonilla-SiLva Eduardo

2003 Racism without racists: color-blind racism and the persistence of racial inequality in the United States, Rowman \& Littlefield, Maryland.

Buehler James W., Donna F Stroup, Douglas N. Klaucke and Ruth L. Berkelman 1989 "The reporting of race and ethnicity in the national notifiable diseases surveillance system », Public Health Reports, 104, pp. 457-465.

Caillavet Chantal

2006 "Commentary on paper entitled "Comparative perspectives : Latinos, the census and race in the United States" by Clara Rodríguez presented at the conference "Des catégories et de leurs usages dans la construction sociale d'un groupe de référence: 'race', 'ethnie' et 'communauté' aux Amériques" ", December 13-15, Paris.

Chevan Albert

1990 "Hispanic racial identity: beyond social class », paper presented at the American Sociological Association meetings, August 14, Washington, DC.

Choldin Harvey M.

1986 Statistics and politics - the Hispanic issue in the 1980 Census, Demography, 23 (3), pp. 403-418.

Christenson Matthew

2003 «Puerto Rico census 2000 responses to the race and ethnicity questions », Population Division, working paper $n^{\circ} 77$, US Census Bureau, Washington, DC. 
COATES Julia

2006 "Blood quantum and the dawes rolls ", The Columns, Spring, Cherokee Heritage Center Tahlequah, OK.

DAvis James F.

1991 Who is black? One nation's definition, Pennsylvania State University Press, University Park, PA.

Denton Nancy A. and Douglas S. MasseY

1989 "Racial identity among Caribbean Hispanics: the effect of double minority status on residential segregation ", American Sociological Review, 54, pp. $790-808$.

Denton Nancy A. and Jacqueline Villarrubia

2007 «Residential segregation on the Island: the role of race and class in Puerto Rican neighborhoods ", Sociological forum, 22 (1), pp. 51-76.

Diaz McConnell Eileen and Edward A. Delgado-Romero

2004 "Latino panethnicity: reality or methodological construction? ", Sociological Focus, 37 (4), pp. 297-313.

DuanY Jorge

1998 "Reconstructing racial identity: ethnicity, color and class among Dominicans in the United States and Puerto Rico ", Latin American Perspectives, 25 (3), pp. 147-172.

\section{EschваCH Karl and Christina Gomez}

1998 "Choosing Hispanic identity: ethnic identity switching among respondents to high-school and beyond », Social Science Quarterly, 79 (1), pp. 74-90.

Espino Rodolfo and Michael Franz

2002 "Latino phenotypic discrimination revisited: the impact of skin color on occupational status », Social Science Quarterly, 83 (2), pp. 612-623.

EVINGER Suzanne

1996 "How to record race », American Demographics, 18 (5), pp. 36-42.

FONER Nancy

1998 "West Indian identity in the diaspora: comparative and historical perspectives », Latin American Perspectives, 25 (3), pp. 173-188.

Golash-Boza Tanya

2006 "Dropping the hyphen? Becoming Latino(a)-American through racialized assimilation ", Social Forces, September, 85 (1), pp. 27-55.

Gomez Christina

2000 "The continual significance of skin color: an exploratory study of Latinos in the Northeast ", Hispanic Journal of Behavioral Sciences, 22 (1), pp. 94-103.

Gonzales Patrisia and Roberto Rodríguez

2004 «Census pushes for Indian removal », Column of the Americas, Universal Press Syndicate, December 17. 
Gossett Thomas

1963 Race: the history of an idea in America, Schocken Books, New York.

Gould Stephen Jay

1981 The mismeasure of Mam, Norton, New York.

GuZmán Betsy and Eileen Diaz McConnell

2002 "The Hispanic population: 1990-2000 growth and change ", Population Research and Policy Review, 21, pp. 109-128.

HANEY LóPEZ Ian

1996 White by law: the legal construction of race, New York University Press, New York.

HARris David and Jeremiah Joseph SiM

2002 "Who is multiracial? The fluidity of racial identity among United States adolescents ", American Sociological Review, 67 (4), pp. 614-627.

Harris Marvin, Josildeth Gomes Consorte, Joseph LANG and Bryan Byrne

1993 "Who are the Whites? Imposed census categories and the racial demography of Brazil », Social Forces, 72, pp. 451-462.

Hernandez Tanya

2002 "Multiracial matrix », Cornell Law Review, 87, pp. 1094-1174.

Hirschman Charles, Richard Alba and Reynolds Farley

2000 " The meaning and measurement of race in the US census: glimpses into the future », Demography, 37 (3), pp. 381-393.

Itzigsohn José, Silvia Giorguli and Obed VazQuez

2005 "Immigrant incorporation and racial identity: racial self-identification among Dominican immigrants ", Ethmic and Racial Studies, 28 (1), pp. 50-78.

JORDAN Winthrop

1968 White over Black: American attitudes toward the Negro, 1550-1812, Penguin Books, Baltimore.

KatZMAn Martin

1968 "Discrimination, subculture and the economic performance of Negroes, Puerto Ricans and Mexican-Americans ", American Journal of Economics and Society, 27 (4), pp. 371-375.

LANDALE Nancy S. and Ronald S. Oropeza

2002 "White, Black, or Puerto Rican? Racial self-identification among Mainland and Island Puerto Ricans"), Social Forces, 81 (1), pp. 231-254.

LOGAN John R.

2004 "How race counts for Hispanic Americans ", SAGE Race Relations Abstracts, 29 (1), pp. 7-19. 
Martin Elizabeth, Theresa J. DeMaio and Pamela C. Campanelli

1990 "Context effects for census measures of race and Hispanic origin », Public Opinion Quarterly, 54 (4), pp. 551-566.

MARTÍNEZ-EChaZÁBAL Lourdes

1998 "Mestizaje and the discourse of national/cultural identity in Latin America, 1845-1959 », Latin American Perspectives, 25 (3), pp. 21-42.

Massey Douglas S. and Nancy A. Denton

1993 American apartheid: segregation and the making of the underclass, Harvard University Press, Cambridge, MA.

McKenney Nampeo R. and Claudette E. BennetT

1994 "Issues regarding data on race and ethnicity: the census bureau experience ", CDC-ATSDR Workshop, Public Health Reports, $108(1)$, pp. 16-25.

MCKenney Nampeo R. and Arthur R. CResCe

1993 "Measurement of ethnicity in the US census Bureau », Challenges of measuring an ethnic world: science, politics and reality. Proceedings of the Joint Canada - United States conference on the measurement of ethnicity, April 1-3, 1992, US Government Printing Oflice, Washington, DC.

McKenney Nampeo R., Claudette Bennett, Roderick Harrison and Jorge Del Pinal

1993 "Evaluating racial and ethnic reporting in the 1990 census », reprinted from the Proceedings of the section on survey research methods of the American statistical association, American Sociological Association, Washington, DC, pp. 66-74.

MORNING Ann

2008 "Ethnic classification in global perspective: across-national survey of the 2000 census round », Population Research Policy Review, 27, pp. 239-272.

Murguía Edward and Edward E. Telles

1996 "Phenotype and Schooling among Mexican Americans ", Sociology of Education, 69 (4), pp. 276-289.

OBoler Suzanne

1995 Ethnic labels/Latino lives: identity and the politics of (re)presentation in the United States, University of Minnesota Press, Minneapolis, MN.

Omi Michael and Howard Winant

1995 Racial formation in the United States, Routledge, Kegan and Paul, New York.

Padilla Maria T.

2001 "Changing face of America-mixed", Orlando Sentinel, March 13, p. Al.

Porter Eduardo

2001 «Even 126 sizes don't fit all », Wall Street Journal, March 2, p. B1. 
Portes Alejandro and Rubén Rumbaut

2001 Legacies: the story of the immigrant second generation, Russell Sage Foundation and University of California Press, Berkeley, CA.

RAMIREZ Roberto R.

2005 "Analysis of multiple origin reporting to the Hispanic origin question in census 2000 ", Population Division, working paper $n^{\circ} 77$, US Census Bureau, Washington, DC.

Relethford John H., Michael P. Stern, Sharon P. Gaskill and Helen P. Hazuda

1983 «Social class, admixture, and skin color variation in Mexican-Americans and Anglo-Americans living in San Antonio, Texas ", American Journal of Physical Anthropology, 61, pp. 97-102.

Rodríguez Clara E.

1990 "Racial identification among Puerto Ricans in New York », Hispanic Journal of Behavioral Sciences, 12 (4), pp. 366-379.

1991 Puerto Ricans; born in the USA, Westview Press, Boulder, CO [1989].

1991a "The effect of race on Puerto Rican wages », in Edwin Meléndez, Clara Rodríguez, and Janice Barry Figueroa (eds), Hispanics in the Labor Force: Issues and Policies, Plenum Press, New York.

1991b "Why other is our second fastest growing racial category », Letter to the Editor, New York Times, April 4, p. A14.

1992 "Race, culture and Latino "Otherness" in the 1980 census », Social Science Quarterly, 73 (4), pp. 930-937.

1994 "A summary of Puerto Rican migration to the United States », in Cynthia Garcia Coll and Gontram Lamberty (eds), The Puerto Rican women and children: issues in health, growth and development, Plenum Press, New York, pp. 11-28.

1996 "Racial themes in the literature on Puerto Ricans », in Gabriel Haslip-Viera and Sherrie Baver (eds), Latinos in New York: commumities in transition, University of Notre Dame Press, Notre Dame, IN.

2000 Changing race: Latinos, the census and the history of ethnicity in the United States, New York University Press, New York.

2009 "Counting Latinos in the US census », in José A. Cobas (ed.), How the United States racializes Latinos: at home and abroad, Paradigm Publishers, Boulder and London.

Rodrígufz Clara E., Aida CAstro, Oscar Garcia and Analisa Torres

1991 "Latino racial identity: in the eye of the beholder », Latino Studies Journal, 2 (3), pp. 33-48.

Rodríguez Clara E. and Hector CORdERo GuZMÁN

1992 "Placing Race in Context », Ethnic and Racial Studies, 15 (4), pp. 523-542.

ROMÁN Iván

2001 «Puerto Ricans confront race issue», Orlando Sentinel, March 31, p. Al. 


\section{Rosenbaum Emily}

1996 "The influence of race on Hispanic housing choices: New York City, 1978-1987 », Urban Affairs Review, 32 (2), pp. 217-243.

\section{SABbagh Daniel}

2009 The collection of ethnoracial statistics: developments in the French controversy, French-American Foundation, New York.

\section{SAENZ Rogelio}

2004 Latinos and the changing face of America. The American people census 2000 population reference bureau, Russell Sage Foundation, New York.

SAFA Helen

1998 "Race and national identity in the Americas", Latin American Perspectives, 25 (3), pp. 21-42.

SANDERS ThOMPSON Vetta L.

2001 "The complexity of African American racial identification », Journal of Black Studies, 32, pp. 155-165.

\section{SANJEK Roger}

1994 "The enduring inequalities of race », in Stephen Gregory and Roger Sanjek (eds), Race, Rutgers University Press, New Brunswick.

SCARR Harry A.

1994 "Statement of Harry A. Scarr, acting Director, Bureau of the Census ", at the Hearings before the subcommittee on census, statistics and postal personnel of the committee on Post Office and Civil Service, House of Representatives, 103 Congress, first Session, June 30, 1993, serial $\mathrm{n}^{\circ} 103-7$, pp. 3-17.

Serrano José E.

2004 "Serrano succeeds in retaining "Other" race option on census form: hispanic organizations applaud action ", Press Release, November 22, Washington, DC.

Stanton William

1960 The Leopard's spots: scientific attitudes towards race in America, 1815-1859, University of Chicago Press, Chicago.

Suro Robert and Sonya TAFOYA

2004 Dispersal and concentration: patterns of Latino residential settlement, Pew Hispanic Center, Washington, DC.

Sivarns Rachel

2004a "Hispanics Debate Racial Grouping By Census», New York Times, October 24, p. 1.

2004b «National Briefing», New York Times, November 23. [http://query. nytimes.com/gst/fullpage.html?res=9E01EEDE173EF930A15752C1A962 9 C8B63\&fta=y]. 
TAFOYA Sonya

2004 Shades of belonging: Latinos and racial identity, Pew Hispanic Center, Washington, DC.

Telles Edward E.

1995 "Who are the Morenas? », Social Forces, 73 (4), pp. 1609-1611.

TelLes Edward E. and Edward Murguía

1990 "Phenotypic discrimination and income differences among Mexican Americans ", Social Science Quarterly, 71 (4), pp. 683-696.

Thomas Edward A.

2005 The world almanac and book of facts for booksellers, World Almanac Books, New York.

TIENDA Marta and Vilma OrTIZ

1986 " "Hispanicity" and the 1980 Census", Social Science Quarterly, 67, pp. 3-20.

TORRes Arlene and Norman E. WhitTen (eds)

1998 Blackness in Latin American and the Caribbean, Vol. II, Indiana University Press, Bloomington and Indianapolis.

TORres-Saillant Silvio

1998 "The tribulations of blackness: states in Dominican racial identity », Latin American Perspectives, 25 (4), pp. 126-146.

Tucker Clyde, Ruth McKay, Brian Kojetin, Roderick Harrison, Manuel de La Puente, Linda STINSON and Ed RoBISON

1996 " Testing methods of collecting racial and ethnic information: results of the current population survey supplement on race and ethnicity », Statistical Note, 40, Bureau of Labor Statistics, Statistical Note Series, Washington, DC.

US Bureau of the Census

19931990 Census of Population: Social and Economic Characteristics, 1990 CP-2-1.

US Dept. of Labor, Bureau of Labor Statistics

1995 "A CPS supplement for testing methods of collecting racial and ethnic information: May, 1995 », Bureau of Labor Statistics Statistical, Working Papers series, November, Washington.

US Oflice of Management and Budget

1995 "Standards for the classification of federal data on race and ethnicity: notice ", Federal Register, part. VI, vol. 60, n 166, pp. 44674-44693, August 28.

VAQUERA Elizabeth and Jamie M. DoYLE

2005 "What race am I? Change in racial choice among Hispanic adolescents », The Annual Meetings of the American Sociological Association, August, The American Sociological Association, Philadelphia. 
VAQUERA Elizabeth and Grace KAO

2006 "The implications of choosing no-race on the salience of Hispanic identity: how racial and ethnic background intersect among Hispanic adolescents "), Sociological Quarterly, 47, pp. 375-396.

VÉrAN Jean-François

2006 "Commentary on paper entitled "Comparative perspectives: Latinos, the census and race in the United States" by Clara Rodríguez ", presented at the conference " Des catégories et de leurs usages dans la construction d'un groupe de référence : "race", "ethnie" et "communauté" aux Amériques 》, 13-15 December, Paris, France.

WaGLeY Charles

1965 "On the concept of race in the Americas ", in Dwight B. Heath and Richard N. Adams (eds), Contemporary cultures and societies of Latin America, Random House, New York.

Waters Mary C.

1999 Racial identities: West Indian immigrant dreams and American realities, Russell Sage Foundation and Harvard University Press, Cambridge, MA. 